Reviews

\title{
Being Human: Ethics, Environment, and Our Place in the World, by Anna L. Peterson. Berkeley: University of California Press (2001), x, 289 pp.
}

\section{Reviewed by Susan J. Armstrong, Department of Philosophy, Humboldt State University, Arcata, Ca. 95521}

Anna Peterson suggests that we should view environmental ethics as "lived ethics," the primary models for which are religious. What is distinctive about this book is the author's focus on "the internal dynamics that make religion such a potent force" in our ethical ideas and practices. She is interested in finding out what makes religious ethics powerful and "how they might need to change in response to environmental crisis" (p. 11).

Peterson identifies several elements that contribute to the power of religious ethics. One such element is narrative. What distinguishes religious narrative is the presence of the sacred: forces, ideas and events with meaning beyond the human. Peterson is interested in narratives that are not only lived but "also have the potential to challenge, rather than reinforce, dominant worldviews" (p. 20). Future visions, "ideal-setting," is essential if a narrative is to lead to significant social change (p. 22).

Peterson provides chapters on human nature in the Western tradition, the relational self of Buddhism and Taoism, person and nature in Native American world-views, feminist ethics, the social construction of nature and human nature, and recent studies of animal behavior. The book concludes with two chapters which examine the "potential for revision in mainstream ethics" (p. 26). Each chapter is prefaced with a summary of its contents.

In her discussion of the Western tradition, Peterson points out that while Protestantism has often seen human life on earth as radically separated from the spiritual realm, Catholicism has perceived greater continuity between the human and the divine. But both forms of Christianity have generally stressed human superiority and the view that the only internal relationship for "rational man" is with God or universal reason.

Social constructionism asserts that there is no original or universal self: "a subject can have meaning only in and through particular cultural, social, or linguistic conditions" (p. 54). While social constructionism offers a "welcome humility about our own ways of seeing and being in the world" (p. 76), it also harbors a number of harmful assumptions. For example, while all forms of social constructionism deny that there is a single way of being human, most social constructionists affirm a "generic humanness," which is radically superior to the non-human in that human signification creates the world (p. 58). Extreme social constructionism thus actually denies nature's independent existence. In addition, since according to constructionism ideas and interpretation are all we have, this approach does not seriously consider alternative worldviews as sources of actual knowledge about the world. Further, extreme constructionism can undermine arguments for protection of nonhuman species or wilderness areas on the grounds that it is all about ideas anyway. Peterson affirms Kate Soper's and Katherine Hayles's calls for a "productive tension between realism and construction" (p. 74), a position that combines the constructionist insight that we can have no unmediated apprehension of nature with the realist claim that the world consists of more than human mediations.

Peterson begins her chapter on Asian perspectives with a sophisticated discussion of the risks in comparative ethics. Peterson admits that we may be wrong about what ideas mean to different groups, and that comparative ethics does risk "overestimating the causal importance of ideas" (p. 97). But she does not agree that comparative ethics is an immoral venture in cultural imperalism. She affirms that while comparative ethics is "an inherently messy and risky project," it is worth examining other ethical traditions for the light shed on our own as contingent and perhaps in need of revision.

The outcome of her venture in comparative ethics is her assertion that certain world-views have a greater "affinity" for environmental care or harm than others. Despite the difficulties in ascertaining the "effective histories" of Buddhism and Taoism, a task "complicated by post-Buddhist and post-Taoist innovations," she does believe that the ideas of the relational self in Buddhism and Taoism do provide a basis for "greater awareness of human dependence on the natural world" and concomitant behavior (p. 99).

Peterson approaches the question of Native American world-views with an admirable awareness of the diversity of Amerindian traditions of thought as well as the long history of oppression and genocide by colonial and post-colonial governments in the Americas. In acknowledgment of the distinctiveness of each group, she discusses only two traditions: those of the Koyukon of interior Alaska and the Navajo. She adopts the approach of identifying common themes which contrasted with the beliefs of the European invaders. One such theme is a view of a world peopled with other-than-human persons, which are not only persons but kin. In addition, Amerindians viewed their 
Reviews

world as relational. Restraint, humility, and respect toward the natural world result from such relationships.

Peterson introduces her discussion of feminist ethics by noting that critiques coming from within a culture may be more likely to generate changes in attitudes and behavior. Internal challenges also "underline the fact that not all members of a group are equally responsible for dominant attitudes and institutions" (p. 128). Peterson discusses feminist critiques as "perhaps the most powerful internal challenges" to dominant Western ideas (p. 126). Feminist world-views, like religious ones, "seek and often achieve a link between ethical ideas and real life" (p. 129). Peterson wants to be clear that she does not think that feminism is itself a religion, but that it offers a "fuller vision of the role of moral ideas" than do many other philosophies. Feminism emphasizes relationality between persons, feelings, embodiment, and context. In contrast to many Asian traditions, moreover, feminism usually attributes a degree of individual autonomy and stability to selves. Peterson goes on to discuss ecofeminism as not simply a hybrid but as a distinctive approach, offering a new conceptual framework. Ecofeminism expands moral relationships to encompass those with nonhuman animals, natural objects, landscapes, and nature in general.

Peterson then turns to Western science, a "challenge from within the heart of reason itself" (p. 153). She focuses on evolutionary theory and in particular on studies of animal behavior. Peterson marshals evidence indicating that "the emergence of distinctively human qualities was gradual, nonlinear, and certainly not inevitable" (p. 160). She accepts the core thesis of sociobiology: that "many human behaviors have evolutionary, thus biological, roots" (p. 168). Peterson cites ethological studies to illustrate that animals have thoughts, purposes, beliefs, and desires. Thus, for Peterson, the human/nonhuman difference is a "continuum with fuzzy boundaries and innumerable areas of overlap" (p. 171).

A number of environmental philosophers argue that ecology has specific implications for models of human nature, some emphasizing the internal relatedness of all organisms in a way that makes the individual only a part of the system. Human social life, however, is usually exempted from this analysis. She finds this exemption unsatisfactory and rejects attempts, such as found in the writings of Holmes Rolston, to split culture from nature. She also rejects Callicott's urging that we extend holistic naturalism to the human sphere by accepting life "as it is [biologically] given" (p. 182).

Peterson's chapter "In and Of the World" provides what she terms "chastened constructionist anthropology" as the best answer to the question of the relationship of human beings to the natural world. In developing this approach, Peterson relies on E.O. Wilson's notion of "gene-culture coevolution", operating by means of "epigenetic rules": regularities of sensory perception and mental development which "channel" how culture is acquired (p. 189). Human beings are both natural and cultural, just as other species are both biological and environmental. Both human beings and other animals shape their environments, though human beings do this to a greater extent than other animals (p. 196).

Peterson emphasizes that we need to take such differences between human beings and nature seriously, without using those differences to justify domination. Following Plumwood, Thompson rejects the "expanded self" of deep ecology as inadequate and commends the Buddhist idea of the importance of practices such as meditation and vegetarianism as productive of relational visions of the self. She discusses forms of Christian eco-theology that are not based on claims of human superiority, such as Philip Hefner's notion of "God's created cocreators" and affirms Sallie McFague's conception of the earth as the body of God, a God who is incarnated in all matter. According to this perspective, as Sallie McFague asserts, human beings should be "recentered as God's partners in helping creation to grow and prosper in our tiny part of God's body" (p. 216).

While some Christian environmentalists reject the stewardship ethic as anthropocentric, Peterson argues that such models have the merit of addressing the human-nature relationship directly and in addition acknowledge human weakness and ambivalence (p. 218). According to the stewardship ethic, God is the ground of intrinsic value, preventing the triumph of human instrumental values as the last word in our dealings with the natural world. Peterson rejects J. Baird Callicott's effort to eliminate God from stewardship ethics on the grounds that such a revised ethic will not function the same in providing motivation. She maintains that religious ethics are not simply "literal elements" which can and should be discarded from philosophy: religious ethics are "integrated into a complex cultural whole" (p. 220).

Nevertheless stewardship ethics are not fully adequate to the task. We need new, powerful stories in order to generate different ideas and different ways of living in the world. One very compelling story is that of evolution. However, Peterson notes that the evolutionary story lacks a vision of the future. While she is fully aware of the dangers of utopian dreams, she defends religious ideals as having ethical and political force. Thus the question becomes one of finding narratives that incorporate future visions as well as make sense in the context of contemporary Western cultures. Peterson finds hints of a new "moralscape" in both bioregionalism and in Rolston's concept of "storied residence." Understanding community as based on contiguity as well as similarity broadens community to include nonhuman residents of a place. While such ecological awareness is painful due to the human- 
Reviews

inflicted damage to the world, Peterson concludes by assuring the reader that we are not alone because we are connected to the nonhuman world and to the many people who also love that world.

Now, as is traditional at the end of a book review, for the critique. Overall the book is a well-written, comprehensive review of the literature rather than a presentation of a distinctive position. The comprehensiveness is at times superficial, in that Peterson mentions a number of ideas which are not developed: e.g., we are urged several times to take indigenous constructions of nonhuman nature seriously, but we are given no suggestions as to how to go about doing so. The book is somewhat repetitious and would have benefited from editorial pruning.

Peterson's emphasis on Protestant and Roman Catholic thought could usefully be complemented by an examination of the rather different assumptions concerning the human/nature relationship found in Eastern Christianity, as well as in the rich history of Celtic Christianity in the British Isles. Her characterization of William Cronon's views concerning wilderness as one in which "anything goes" is inaccurate (p. 65), since in the same essay from which she draws her criticism, Cronin stresses that our tasks are to make sense of the inscrutable autonomy of the natural world and of our obligations to that world. Her discussion of holism in environmental philosophy would benefit from Don Marrietta's analysis of types of deontic and ontological holism (p. "Ethical Holism and Individuals" in For People and the Planet (Temple, 1995). And finally, Peterson makes no mention of the highly germane process theology tradition and the several applications of process philosophy to environmental ethics which have been published in the last twenty years.

Despite these weaknesses and omissions, Being Human is an admirable achievement which by its thoughtful assessment of disparate ideas and traditions furthers our understanding of our relationship to ourselves and to the nonhuman world.

\section{Geographical Identities of Ethnic America: Race, Space and Place, Kate Berry \& Martha Henderson (editors). Reno: University of Nevada Press (2002), 311 pp..}

\section{Reviewed by Mary E. Valmont, Valmont Consulting, Brooklyn, New York.}

Geographical Identities of Ethnic America: Race, Space and Place is an edited volume that explores and strives to understand the complex relationships between ethnic identity and place. How is geography relevant to understanding ethnicity and race? The editors, Berry and Henderson, respond that it is because such identities are not only created by the labels but also by the spaces and places in which they exist. This collection presents 13 analytical essays that explore the interactions of ethnic identities and the recreation of space and place in the United States and Canada. In addition to providing rich and engaging historical and geographical descriptions, the articles contribute an array of ethnographic and statistical methodologies for conducting such analysis.

In their introduction, Berry and Henderson put forth several assumptions, which resonate with varying success, throughout the essays: place matters in the experience and processes that shape racial and ethnic identity; and such identities are socially constructed. Although the editors note that physical scientific evidence does not support the concept of autonomous races, the foundation of this book is the reality that ethnic and racial identities have social implications for the classification, representation and power differentials that exist among different racial/ethnic groups. They define race as a "condition of individual and collective identity...as a flexible element of social structure...subject to continual reinterpretation" (p. 4). As an example of the fluidity of ethnic and racial identities, Berry and Henderson report that the U.S. Census 2000 increased the number of racial categories from five to fifteen.

Berry and Henderson organized the chapters around three scales: macro, meso and micro. As defined by Berry and Henderson, the essays examine race and ethnicity in North America from either the macro level (e.g. broad national or international perspective) or, the meso level (e.g., connections between broader processes and events and particular places) or, the micro level (e.g., specific places and landscaping).

The first three essays fall within the classification as macro - examining race and ethnicity from a broad perspective. These essays include a demographic comparison of Hispanic and Asian groups during the 1980s (Roseman), changes in residential segregation patterns between Black and white Americans between 1970 and 1990 (Deskins and Bettinger) and charting the immigrant experience of Asian Indians in Canada (Fernandez). 